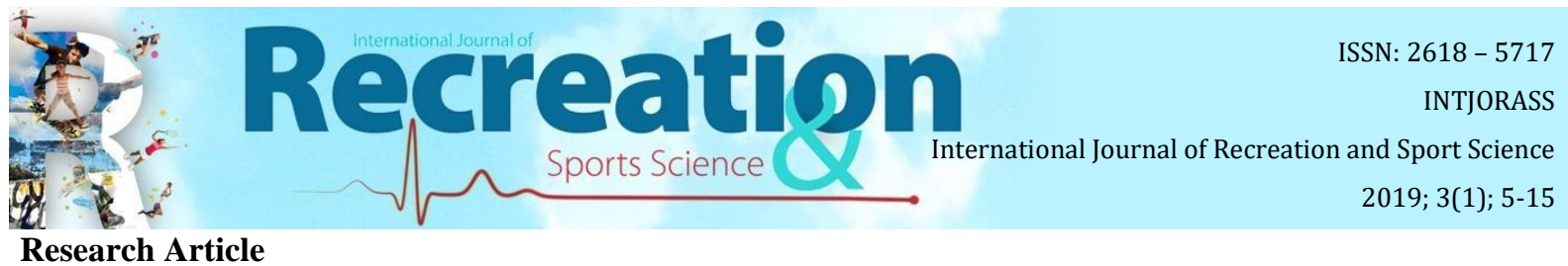

\title{
Investigation of Perceived Service Quality of Youth Centers
}

\author{
Bahadır ALİGÜL * H. Erdem MUMCU** Abdullah ÖZLÜYEN*** Neşe MUMCU****
}

\begin{abstract}
Youth Centers serve for the development of youth at more than 180 locations in 81 cities within the Ministry of Youth and Sports and it is important to be known the quality of activities offered to young people. This study was conducted to measure perceived service quality of youth centers operating in TR42 Level 2 region. In this research, among the quantitative research methods, the survey technique was applied and the opinions of the participants were applied. This research, which was conducted to determine the relationship between age, gender, duration of membership and youth center variables and physical environment quality, output quality and interaction quality sub-dimensions among young people aged between 15-29 who are members of Youth Centers of Ministry of Youth and Sports that serve in TR42 Level 2 Region, was carried out using a cross-sectional approach, which is one of the general screening model, and a relational screening model. In this regard, the opinions of the members of the Youth Centers operating in the TR42 level 2 region of the Ministry of Youth and Sports have been consulted. For this purpose, the data collection tool which was developed by Aycan (2005) and which was evaluated by Polat et al. (2013) in terms of validity and reliability was used. Findings that obtained from the study were processed in SPSS 21.0 for Windows Program and the findings have been reached. As a result of the research, there were no significant differences in terms of gender variable, but significant differences were found in terms of age, duration of membership and youth center variables.
\end{abstract}

Keywords: Youth, Youth Center, Service Quality.

\section{Gençlik Merkezlerinde Algılanan Hizmet Kalitesinin Araştırılması}

\section{$\ddot{O} \mathbf{z}$}

Gençlik Merkezleri, Gençlik ve Spor Bakanlığı bünyesinde 81 ilde ve 180’den fazla noktada gençliğin gelişimi için hizmet vermekte olup, gençler için sunulan faaliyetlerin kalitesinin bilinmesi önem taşımaktadır. Bu çalışmada TR42 Düzey 2 bölgesinde faaliyet gösteren gençlik merkezlerinin algılanan hizmet kalitesini ölçmek amacıyla gerçekleştirilmiştir. Araştırmada nicel araştırma yöntemlerinden anket tekniği uygulanmış ve katılımcıların görüşlerine başvurulmuştur. Gençlik ve Spor Bakanlığı TR42 düzey 2 bölgesinde faaliyet gösteren Gençlik Merkezlerine üye olan 15-29 yaş aralığındaki gençlerin yaş, cinsiyet, üyelik süresi ve üye olduğu gençlik merkezi değişkenleri ile fiziksel çevre kalitesi, çıktı kalitesi ve etkileşim kalitesi alt boyutları arasındaki ilişkiyi tespit etmek amacı ile yapılan bu araştırma, genel tarama modellerinden biri olan kesit alma yaklaşımıyla ve ilişkisel tarama modeliyle yapılmıştır. Bu doğrultuda, Gençlik ve Spor Bakanlığı TR42 düzey 2 bölgesinde faaliyet gösteren Gençlik Merkezlerine üye gençlerin görüşlerine başvurulmuş ve bunun için 2005 yılında Ali Aycan tarafından geliştirilen ve 2013 yılında Polat ve Arkadaşları tarafından geçerlik ve güvenirlik çalışması yapılan veri toplama aracı kullanılmıştır. Araştırmada elde edilen bulgular SPSS 21.0 For Windows Programında işlenerek bulgulara ulaşılmıştır. Yapılan araştırma sonucunda, cinsiyet değişkeni açısından anlamlı düzeyde bir farklılık bulunmazken, yaş, üyelik süresi ve üye olunan gençlik merkezi değişkenleri açısından anlamlı düzeyde farklılıklar tespit edilmiştir.

Anahtar Kelimeler: Gençlik, Gençlik Merkezi, Hizmet Kalitesi.

\footnotetext{
*Provincial Directorate of Youth and Sport, Kocaeli-TURKEY, bahadiraligul@gmail.com https://orcid.org/0000-00032679-338X

**Hitit University, Sports Science Faculty, Çorum-TURKEY, erdemumcu@ gmail.com https://orcid.org/0000-0003-43255575

${ }^{* * * *}$ Yıldırım Beyazıt University, Sports Science Faculty, Ankara-TURKEY, abdullahozluyen@hotmail.com https://orcid.org/0000-0003-1945-3731

${ }^{*}$ Hitit University, Sports Science Faculty, Çorum-TURKEY, nese-baykal@hotmail.com https://orcid.org/0000-00033438-907X 


\section{Introduction}

Young people are the most dynamic actors of social life. There has been a serious awareness in the international public opinion about increasing the participation of young people, especially in the last 20 years. The encouragements of the participation of young people in decision-making processes that concern them or, in general, on all social issues has been agreed upon. International-level gains about the youth, guide national-level studies. In Turkey, like many countries, it is wanted to encourage the participation of young people with the support brought by the regulations (Özer, 2011).

Today, the importance that is given to the young population constituting a significant part of the population of our country is increasing, and the investments and services which are produced are developed in terms of quality and quantity. In this development process in the youth field, we can say that the content, scope and diversity of the youth work carried out by the help of the government is an important issue for the present and future of the youngster (Parlar, 2014).

Youth services in Turkey are carried out by the Youth Centers within the Youth Services and Sports Provincial Directorates under the umbrella of the ministry of youth and sports. In this sense, the quality of activities which run with the help of the government is a decisive factor for the existence of a conscious and cultured youth. In this context, the number of youth centers, which were 230 in 2016, have reached 283 in November 2018. As of November 2018, there are a total of 2 million 11 thousand 717 registered young people in our youth centers. Furthermore, 753 youth leaders, including 382 women and 371 men, are working in these centers (GSB, 2018).
Globalized and uni-polarized sectoral developments in the world bring about rapid changes with itself. These changes necessitate making innovations not only in the private sector but also in the public sector. A changing and developing business, whether it is public or private, will ensure the continuity of its operation by following the developments of the age, and the businesses that do not follow these developments will not be able to proceed because they will be away from development and change.

No matter which sector it is, it is impossible for a seller who provides multiple services to standardize the service. Each unit of the service is different from the other units of the same service. The quality, satisfaction and time of the service may vary depending on the person who receives it. This makes it difficult to estimate the quality of the service and the product before purchasing the service. Since the services are carried out by the person, their qualities can also change. The service can show a main alteration from one service to another, from customer to customer and one moment to another. The mode of production of the service is formed by the behavior of people. Therefore, the services which are produced and presented by the same person may vary.

This is due to various factors such as the person's morale, workload, and customer's personal characteristics (Mucuk, 1998). The most well-known definition of the service is an activity or benefit that does not result in ownership of anything presented from one group to another. Service production may or may not depend on a physical product (Rust and others, 1996). Service quality is a measure of how much service can meet customer expectations. Providing highquality service is to meet customer expectations (Gökdelen, 2007). The fact 
that the service is abstract, variable, unstockable and inseparable makes service quality measurements difficult. Despite this difficulty, the measurement of service quality is very important for the companies that provide service (Altan and Ediz, 2017).

The result that can be drawn from the studies that directs the service quality literature, the dimensions of the service quality are;

- Service environment (physical environment) quality

- Interaction (customer-worker interaction) quality

- Output quality.

In these studies, it was determined that these three dimensions affected the perception of service quality (Gökdelen, 2007).

In this study, it is aimed to determine the perceived service quality of Youth Centers that serve in the TR42 level 2 region of Youth and Sports General Directorate of Youth Services according to various variables.

\section{Perceived Service Quality}

Nowadays, two elements of success in marketing are to provide high-quality service to customers and to maximize the satisfaction of perceived goods and services. Evaluations of the perceptions of individuals about service quality become meaningful after comparison of expectations and perceptions. The perceived service appears after the evaluation of the total of the service dimensions by the person who receive the service. These dimensions consist of various concrete and abstract elements such as the physical equipment used in providing service, the attitudes and behaviors of the personnel, the environment in which the service is provided (Demirel et al., 2009).

Since the services are abstract in nature, the service quality also has an abstract structure. Therefore, the term 'perceived service quality' is used rather than the concept of service quality.

The perceived service quality is a result of the comparison between an actual service experience (performance) of the customers and their prior expectations of the provide of service and it is considered as the direction and degree of the difference between the expectations of the customers and the perceived performance (Usta and Memiş, 2009).

Parasuraman, Zeithaml and Berry (1988) have developed a conceptual model of service quality. According to these, the perceived service quality is the result of the expectations of the customers about the service and directions of perceptions about service performance during the giving of the service.

According to this approach, which is based on the comparison of the expectations of the customers with the service and their perceptions of the service, if the expected service is greater than the perceived service, the perceived service quality will be lower than satisfactory. If the expected service is equal to the perceived service, the perceived quality will be satisfactory.

In order for the perceived quality by the customers to be considered as the ideal quality, the expected service should be smaller than the perceived service (Devebakan and Aksarayli, 2003).

\section{METHOD}

\section{Research Model}

Quantitative research method was used in the research. The survey method was applied in the study and the opinions of 
the participants were consulted. This research, which was conducted to determine the relationship between the various demographic variables and the quality of the environment, the quality of the output and the quality of the interaction of the sub-dimensions of the young people aged between 15-29 who are the members of Youth Centers of Ministry of Youth and Sports that serve in TR42 Level 2 Region, was carried out using a cross-sectional approach, which is one of the general screening model, and a relational screening model.

\section{Working Group}

The number of members of the Youth Center in the research universe is 45000 and this number increases continuously.

The sample of the study consisted of 388 (95\% Confidence Level) people who are members of the Youth Center in TR 42 Level 2 region, who regularly participate in activities in Youth Centers. The sample group was randomly determined from the 'Proportional Element Sampling' type that was one the 'Element Sampling' method and the surveys were completed in a virtual environment.

\section{Data Collection Tools}

\section{Perceived Service Quality Scale}

The survey method was used as data collection tool. The scale (created by Aycan (2005) that used to determine the perceived level of service quality of the members of the Youth Centers within the scope of the research measures the perception of the quality of the perceived environment quality, interaction quality and output quality in the sub-dimensions. The survey consists of 23 items and the questions between 1-10 constitute physical environment quality, questions between 11-18 constitute Interaction Quality and questions between 19-23 constitute the output quality subdimensions.

\section{Data Analysis}

The t-test, One-Way Anova and Tukey Test were used to determine whether the scores that Youth Center members obtained showed a significant difference at a level of 0.05 significance according to their demographic characteristics.

\section{FINDINGS}

Table 1. Comparison of Perceived Service Quality by Youth Center Members in terms of Gender Variable

\begin{tabular}{lcccccc}
\hline $\begin{array}{l}\text { Perceived Service } \\
\text { Quality }\end{array}$ & Gender & $\mathbf{n}$ & $\overline{\mathbf{x}}$ & $\mathbf{s . s}$ & $\mathbf{t}$ & $\mathbf{p}$ \\
\hline Physical & Male & 186 & 3,56 & 0,69 & $-1,24$ & 0,215 \\
Environment Quality & Female & 202 & 3,46 & 0,74 & & \multirow{2}{*}{0,172} \\
\hline \multirow{2}{*}{ Interaction Quality } & Male & 186 & 4,17 & 0,72 & $-1,37$ & 0,172 \\
\hline \multirow{2}{*}{ Output Quality } & Female & 202 & 4,07 & 0,72 & & \multirow{2}{*}{0,629} \\
\hline
\end{tabular}

$\mathrm{p}>0.05$

According to the data in the table, concerning the gender variable of the Youth Center members, in physical environment quality dimension; $(\mathrm{t}=-1,24)$ and $\mathrm{p}=0,215>0,05)$ in interaction quality dimension; $(\mathrm{t}=-1,37)$ and $\mathrm{p}=0,172>0,05)$ 
and in output quality sub-dimension; $(\mathrm{t}=-$

difference was found. $0,48)$ and $\mathrm{p}=0,629>0,05)$ no significant

Table 2. Comparison of Perceived Service Quality by Youth Center Members in terms of Age Variable

\begin{tabular}{lccccccc}
\hline $\begin{array}{c}\text { Perceived Service } \\
\text { Quality }\end{array}$ & Age & $\mathbf{n}$ & $\overline{\mathrm{x}}$ & s.s & $\mathbf{F}$ & $\mathbf{p}$ & Tukey \\
\hline Physical & $1.14-18$ & 163 & 3,72 & 0,59 & & & $1>2$ \\
Environment & $2.19-24$ & 149 & 3,43 & 0,77 & 15,46 & $0,000^{*}$ & $1>3$ \\
Quality & $3.25-29$ & 76 & 3,21 & 0,74 & & & $2>3$ \\
\hline \multirow{3}{*}{ Interaction Quality } & $1.14-18$ & 163 & 4,22 & 0,70 & & & \\
& $2.19-24$ & 149 & 4,15 & 0,68 & 7,033 & $0,001^{*}$ & $1>2$ \\
& $3.25-29$ & 76 & 3,85 & 0,81 & & & $1>3$ \\
\hline \multirow{3}{*}{ Output Quality } & $1.14-18$ & 163 & 4,12 & 0,71 & & & \\
& $2.19-24$ & 149 & 3,97 & 0,65 & 6,530 & $0,002^{*}$ & $1>3$ \\
\hline
\end{tabular}

$* \mathrm{p}<0.05$

According to the data in the table, concerning the age variable of the Youth Center members, in physical environment quality dimension; $(\mathrm{F}=15,46)$ and $\mathrm{p}=0,000>0,05)$ in interaction quality dimension; $(\mathrm{F}=7,033)$ and $\mathrm{p}=0,001>0,05)$ and in output quality sub-dimension; $(\mathrm{F}=6,530)$ and $\mathrm{p}=0,002>0,05)$ significant difference was found. When we examine the arithmetic means to determine which groups the difference arises from, in the physical environment quality subdimension, it was observed that the average of the $14-18(\overline{\mathrm{x}}=3.72)$ age group was higher than the $19-24(\bar{x}=3.43)$ and $25-29(\overline{\mathrm{x}}=3.21)$ age group. So, it can be said that the age group of 14-18 members have a significantly higher perceived service quality in physical environment quality sub-dimension than the members of the age groups of 19-24 and 25-29. When we examine the findings regarding the age variable in terms of the interaction quality sub-dimension, it is seen that the perceived service quality, which $14-18(\overline{\mathrm{x}}$ $=4.22)$ and $19-24(\overline{\mathrm{x}}=4.15)$ age groups of the member have perceived, is more than the perceived service quality, which 25-29 $(\bar{x}=3.85)$ age group of members have perceived. And also, in output quality sub-dimension, this differences between 14-18 ( $\overline{\mathrm{x}}=4,12)$ and 25-29 $(\overline{\mathrm{x}}=3,77)$ age groups resulted in $14-18$ $(\overline{\mathrm{x}}=4,12)$ age group's favor. 
Table 3. Comparison of Perceived Service Quality by Youth Center Members in terms of Youth Centers Variable

\begin{tabular}{|c|c|c|c|c|c|c|c|}
\hline $\begin{array}{c}\text { Perceived Service } \\
\text { Quality } \\
\end{array}$ & Youth Center & $\mathbf{n}$ & $\overline{\mathbf{x}}$ & S.S & $\mathbf{F}$ & $\mathbf{p}$ & Tukey \\
\hline \multirow{7}{*}{$\begin{array}{c}\text { Physical Environment } \\
\text { Quality }\end{array}$} & 1.Bolu & 63 & 3,41 & 0,40 & \multirow{7}{*}{18,41} & \multirow{7}{*}{$0,000 *$} & $1>2$ \\
\hline & 2.Kocaeli Derince & 55 & 2,95 & 1,03 & & & $1>7$ \\
\hline & 3.Düzce & 49 & 3,61 & 0,86 & & & $\begin{array}{l}4>2 \\
4>1\end{array}$ \\
\hline & $\begin{array}{l}\text { 4.Kocaeli } \\
\text { Uluslararas1 }\end{array}$ & 75 & 3,90 & 0,40 & & & $\begin{array}{l}4>7 \\
5>2\end{array}$ \\
\hline & 5.Kocaeli Körfez & 51 & 3,71 & 0,57 & & & $5>7$ \\
\hline & 6.Sakarya & 57 & 3,73 & 0,52 & & & $\begin{array}{l}6>2 \\
6>7\end{array}$ \\
\hline & 7.Yalova & 38 & 2,96 & 0,39 & & & $3>7$ \\
\hline \multirow{7}{*}{ Interaction Quality } & 1.Bolu & 63 & 3,81 & 0,63 & \multirow{7}{*}{23,20} & \multirow{7}{*}{$0,000^{*}$} & $2>1$ \\
\hline & 2.Kocaeli Derince & 55 & 4,29 & 0,53 & & & $\begin{array}{l}4>1 \\
5>1\end{array}$ \\
\hline & 3.Düzce & 49 & 3,97 & 0,77 & & & $6>1$ \\
\hline & $\begin{array}{l}\text { 4.Kocaeli } \\
\text { Uluslararas1 }\end{array}$ & 75 & 4,24 & 0,60 & & & $\begin{array}{l}7>1 \\
2>7 \\
6>3\end{array}$ \\
\hline & 5.Kocaeli Körfez & 51 & 4,46 & 0,65 & & & $\begin{array}{l}6>3 \\
3>7\end{array}$ \\
\hline & 6.Sakarya & 57 & 4,55 & 0,57 & & & $\begin{array}{l}5>3 \\
4>7\end{array}$ \\
\hline & 7.Yalova & 38 & 3,25 & 0,62 & & & $\begin{array}{l}5>7 \\
6>7\end{array}$ \\
\hline \multirow{7}{*}{ Output Quality } & 1.Bolu & 63 & 3,65 & 0,75 & \multirow{7}{*}{17,71} & \multirow{7}{*}{$0,000 *$} & $\begin{array}{l}2>1 \\
5>1\end{array}$ \\
\hline & 2.Kocaeli Derince & 55 & 4,22 & 0,55 & & & $\begin{array}{l}5>1 \\
4>1\end{array}$ \\
\hline & 3.Düzce & 49 & 3,85 & 0,69 & & & $6>1$ \\
\hline & $\begin{array}{l}\text { 4.Kocaeli } \\
\text { Uluslararas1 }\end{array}$ & 75 & 4,26 & 0,67 & & & $\begin{array}{l}1>7 \\
2>7\end{array}$ \\
\hline & 5.Kocaeli Körfez & 51 & 4,12 & 0,62 & & & $\begin{array}{l}4>3 \\
6>3\end{array}$ \\
\hline & 6.Sakarya & 57 & 4,30 & 0,44 & & & $\begin{array}{l}3>7 \\
5>7\end{array}$ \\
\hline & 7.Yalova & 38 & 3,26 & 0,62 & & & $\begin{array}{l}6>7 \\
3>7\end{array}$ \\
\hline
\end{tabular}

$* \mathrm{p}<0.05$

According to the data in the table, concerning the Youth Center variable of the Youth Center members, in physical environment quality dimension; $(\mathrm{F}=18,41)$ and $\mathrm{p}=0,000>0,05)$ in interaction quality dimension; $(\mathrm{F}=23,20)$ and $\mathrm{p}=0,000>0,05)$ and in output quality sub-dimension; $(\mathrm{F}=17,71)$ and $\mathrm{p}=0,000>0,05)$ significant difference was found. When we examine the arithmetic means to determine which groups the difference arises from, in the physical environment quality sub- dimension, the difference between Bolu Youth Center $(\overline{\mathrm{x}}=3,41)$ and Kocaeli Derince $(\overline{\mathrm{x}}=2,95)$ and Yalova Youth Center $(\overline{\mathrm{x}}=2,96)$ was significantly different in Bolu Youth Center's favor; the difference between Düzce Youth Center $(\overline{\mathrm{x}}=3,61)$ and Kocaeli Derince $(\overline{\mathrm{x}}=2,95)$ and Yalova Youth Center $(\overline{\mathrm{x}}=2,96)$ was significantly different in Düzce Youth Center's favor; the difference between Kocaeli International Youth Center $(\overline{\mathrm{x}}=$ 3,90) and Bolu $(\overline{\mathrm{x}}=2,95)$ and Yalova 
Youth Center $(\overline{\mathrm{x}}=2,96)$ was significantly different in Kocaeli International Youth Center's favor; the difference between Kocaeli Körfez Youth Center $(\overline{\mathrm{x}}=3,71)$ and Kocaeli Derince $(\overline{\mathrm{x}}=2,95)$ and Yalova Youth Center $(\overline{\mathrm{x}}=2,96)$ was significantly different in Kocaeli Körfez Youth Center's favor; the difference between Sakarya Youth Center $(\overline{\mathrm{x}}=3,73)$ and Kocaeli Derince $(\overline{\mathrm{x}}=2,95)$ and Yalova Youth Center $(\overline{\mathrm{x}}=2,96)$ was significantly different in Sakarya Youth Center's favor.

In interaction quality sub-dimension; the difference between Kocaeli Derince $(\overline{\mathrm{x}}=$ $4,29)$ and Bolu Youth Center $(\overline{\mathrm{x}}=3,81)$ and Yalova Youth Center $(\overline{\mathrm{x}}=3,25)$ was significantly different in Kocaeli Derince Youth Center's favor; the difference between Düzce Youth Center $(\overline{\mathrm{x}}=3,97)$ and Yalova Youth Center $(\overline{\mathrm{x}}=3,25)$ was significantly different in Düzce Youth Center's favor; the difference between Kocaeli International Youth Center $(\overline{\mathrm{x}}=$ $4,24)$ and Bolu $(\overline{\mathrm{x}}=3,81)$ and Yalova Youth Center $(\overline{\mathrm{x}}=3,25)$ was significantly different in Kocaeli International Youth Center's favor; the difference between Kocaeli Körfez Youth Center $(\overline{\mathrm{x}}=4,46)$ and Bolu $(\overline{\mathrm{x}}=3,81)$ and Yalova $(\overline{\mathrm{x}}=3,25)$ and Düzce Youth Service $(\bar{x}=3,97)$ was significantly different in Kocaeli Körfez Youth Center's favor; the difference between Sakarya Youth Center $(\bar{X}=4,55)$ and Bolu $(\bar{X}=3,81)$ and $\operatorname{Düzce}(\overline{\mathrm{x}}=3,97)$ and Yalova Youth Center $(\overline{\mathrm{x}}=3,25)$ was significantly different in Sakarya Youth Center's favor.

In the output quality sub-dimension of the study, it was found that the perceived service quality differed significantly in terms of the Youth Center variable. For example, the difference between Sakarya Youth Center $(\bar{x}=4,30)$ and Düzce $(\overline{\mathrm{x}}=3,85)$ and Yalova Youth Center $(\overline{\mathrm{x}}=$ $3,25)$ was significantly different in Sakarya Youth Center's favor and the difference between Kocaeli International Center $(\overline{\mathrm{x}}=4,26)$ and Bolu $(\overline{\mathrm{x}}=3,65)$ and Yalova Youth Center $(\overline{\mathrm{x}}=3,26)$ was significantly different in Kocaeli International Youth Center's favor.

Table 4. Comparison of Perceived Service Quality by Youth Center Members in terms of Duration of Membership Variable

\begin{tabular}{|c|c|c|c|c|c|c|c|}
\hline $\begin{array}{c}\text { Perceived Service } \\
\text { Quality }\end{array}$ & $\begin{array}{c}\text { Duration of } \\
\text { Membership }\end{array}$ & $\mathbf{n}$ & $\overline{\mathrm{x}}$ & S.S & $\mathbf{F}$ & $\mathbf{p}$ & Tukey \\
\hline \multirow{3}{*}{$\begin{array}{l}\text { Physical } \\
\text { Environment } \\
\text { Quality }\end{array}$} & $0-1$ Year & 155 & 3,56 & 0,68 & \multirow{3}{*}{0,59} & \multirow{3}{*}{0,551} & \multirow{3}{*}{-} \\
\hline & 2-3 Years & 152 & 3,48 & 0,77 & & & \\
\hline & $\begin{array}{l}4 \text { Years and } \\
\text { More }\end{array}$ & 81 & 3,47 & 0,70 & & & \\
\hline \multirow{3}{*}{ Interaction Quality } & $0-1$ Year & 155 & 4,13 & 0,69 & \multirow{3}{*}{3,16} & \multirow{3}{*}{$0,042 *$} & \multirow{3}{*}{$\begin{array}{c}\text { 2-3 Year } \\
>4 \text { and } \\
\text { More }\end{array}$} \\
\hline & 2-3 Years & 152 & 4,20 & 0,71 & & & \\
\hline & $\begin{array}{l}4 \text { Years and } \\
\text { More }\end{array}$ & 81 & 3,95 & 0,79 & & & \\
\hline \multirow{3}{*}{ Output Quality } & $0-1$ Year & 155 & 4,03 & 0,68 & \multirow{3}{*}{3,09} & \multirow{3}{*}{$0,046^{*}$} & \multirow{3}{*}{$\begin{array}{c}\text { 2-3 Year } \\
14 \text { and } \\
\text { More }\end{array}$} \\
\hline & 2-3 Years & 152 & 4,06 & 0,68 & & & \\
\hline & $\begin{array}{l}4 \text { Years and } \\
\text { More }\end{array}$ & 81 & 3,82 & 0,80 & & & \\
\hline
\end{tabular}

$* \mathrm{p}<0.05$ 
According to the data in the table, concerning the Duration of Membership variable of the Youth Center members, whereas there was no significant difference in physical environment quality dimension $(\mathrm{F}=0,59$ and $\mathrm{p}=0551>0,05$; in interaction quality dimension $(\mathrm{F}=3,16)$ and $(\mathrm{p}=0,042>0,05)$ and in output quality sub-dimension $\quad(\mathrm{F}=3,09) \quad$ and $\mathrm{p}=0,046>0,05)$ significant difference was found.

When we examine the arithmetic means to determine which groups the difference arises from, in the interaction quality subdimension, the difference between the members who have $2-3$ years $(\bar{x}=4,20)$ memberships and the members who have 4 years and more $(\bar{x}=3,95)$ memberships was significantly different in the members' favor who have 2-3 years memberships. And also, in the output quality sub-dimension, the difference between the members who have 2-3 years $(\bar{x}=4,06)$ memberships and the members who have 4 years and more $(\bar{x}=3,82)$ memberships was significantly different in the members' favor who have 2-3 years memberships.

\section{DISCUSSION AND CONCLUSION}

When we evaluate the results of the study, it is determined that the gender variable doesn't show a statistically significant difference (Table 1). In this case, we can say that the perceived service quality of young members in the Youth Centers operating in TR 42 Level 2 region doesn't differ in terms of gender variable. The reason for this is that it can be interpreted that the women and men members of the Youth Center participate in similar activities in the same youth centers. In the research which was done by Gediz (2012) showed that there is no difference in terms of participating in activities in terms of gender among young members in youth centers.
Concerning the age variable of the Youth Center members, in physical environment quality dimension $(\mathrm{F}=15,46)$ and $\mathrm{p}=0,000>0,05)$; in interaction quality dimension $(\mathrm{F}=7,033)$ and $\mathrm{p}=0,001>0,05)$ and in output quality sub-dimension $(\mathrm{F}=6,530)$ and $\mathrm{p}=0,002>0,05)$ significant difference was found (Table 2).

In physical environment quality subdimension, it was concluded that 14-18 age group of members' perceived quality is significantly more than the other age groups of members. When we examine the findings regarding the age variable in terms of the interaction quality subdimension, it is seen that the perceived service quality, which the age groups of 14-18 and 19-24 members' perceived service quality is significantly more than the age group of 25-29 of members'. Also in the output quality sub-dimension, it was concluded that the age groups of 14-18 and 19-24 members' perceived service quality is higher than the age group of $25-$ 29 members'.

In this case, when we evaluate the young members in the Youth Centers operating in TR 42 Level 2 region in terms of age variable, it's seen 14-18 age group's perceived service quality is significantly high in terms of all 3 dimensions. The main reason for this may be that the members of the age group of 14-18 have lower expectations because their level of education is lower than the age groups 1924 and 25-29. Furthermore, the activities that this age group of young people usually spends time with their friends and go to a place for events can mean that the service received from the centers meet the needs of them. Another reason can be that the courses given in the centers for university and high school exams meet the expectations of young people. In this study, which is done by Ataç (2018), it is concluded that age group of 14-18 young people are satisfied with the services. 
The results of the youth center variable are significantly different in physical environment quality sub-dimension $(\mathrm{F}=18,41$ and $\mathrm{p}=0,000>0,05)$ and $\mathrm{p}=0,000>0,05)$; in interaction quality subdimension $(\mathrm{F}=23,20)$ and $(\mathrm{p}=0,000>0,05)$ and in output quality sub-dimension $(\mathrm{F}=17,71)$ and $\mathrm{p}=0,000>0,05)$ (Table 3). For example; while the perceived service quality of Bolu Youth Center was higher than Kocaeli Derince and Yalova Youth Centers, the perceived service quality of Kocaeli International Youth Center was higher than Bolu, Kocaeli Derince and Yalova Youth Center. When the information about the youth centers in the introduction part of the research was examined, the reason for the low perceived service quality in the physical environment quality sub-dimension of Derince and Yalova Youth Center can arise from the low level of physical adequacy of the building they serve and the low number of working areas. In Gediz's (2012) study, it was found that the physical environment was insufficient at a rate of $32 \%$ among the young people. So, this is an issue that can be affected negatively by young people in terms of service quality.

When we examined the interaction quality sub-dimension in terms of the Youth Center variable, many differences were found. For example: Kocaeli Derince Youth Center has a higher service quality than Bolu and Yalova Youth Center, whereas Kocaeli International Youth Center has significantly a higher service quality than Bolu and Yalova Youth Centers. The reason of low scores of Yalova and Bolu Youth Centers in the interaction quality sub-dimension might be caused by organizational climate, individual factors and environmental factors as well as the cultural reasons.
In the output quality sub-dimension of the study, it was found that the perceived service quality was significantly different in terms of the Youth Center variables. For example, Sakarya Youth Center which has higher average than others has a significant difference in terms of perceived service quality compared to Bolu - Düzce and Yalova Youth Centers. There can be many reasons for significant differences that was obtained in every three sub-dimensions of the Youth Center variable. For example, In the physical environment quality sub-dimension, facilities and buildings of Youth Centers vary. This difference may affect the results of interaction and output quality either positively or negatively and whether the buildings which provide services are private or within another institution may affect the perceived service quality. In a study conducted by Aycan (2005), there is no significant difference the youth center members according to the sub-dimensions of service quality. When we consider the results reached in terms of the duration of membership variable, while there was no significant difference in physical environment quality dimension $(\mathrm{F}=0,59$ and $\mathrm{p}=0551>0,05)$, in the interaction quality $(\mathrm{F}=3,16)$ and $(\mathrm{p}=0,042>0,05)$ and in the output quality sub-dimensions $(\mathrm{F}=3,09)$ and $\mathrm{p}=0,046>0,05)$ significant difference was found (Table 4).

In the interaction quality sub-dimension, the difference between the members who have 2-3 years memberships and the members who have 4 years and more memberships was significantly different in the members' favor who have 2-3 years memberships. And also, in the output quality sub-dimension, it was concluded that the perceived service quality of the members who have 2-3 years memberships was higher than the members who have 4 years and more 
memberships. The reason why the perceived service quality of the members who have 2-3 years memberships is higher than others in interaction and output quality sub-dimensions can arise from that the variety of services and activities provided to youth have increased after 2011. The reason why the perceived service quality of the members who have 4 years and more membership is low can be that their education levels may be higher than those members who have 2-3 years of memberships and therefore their expectations from youth center activities may be different. This opinion supports the decrease in the perceived services quality of Youth Center members as their age increases. As a result, the physical conditions of some centers are better than others, so this improves the quality of the service On the other hand, it is seen that there is an intense participation in the activities carried out in youth centers and the satisfaction of the young people who receive service here has decreased when they get older. The main reason for this situation can be said to be the qualitative problems of the activities carried out for middle age young groups. With the increasing the diversity of education and cultural services provided in Youth Centers, it is thought that especially there is a need for sportive qualitative activities.

\section{REFERENCES}

Altan, Ş. ve Ediz, A. (2017). Türkiye'de Yüksek Hizli Tren (Yht) İçin Hizmet Kalitesinin Ölçümü. Gazi Üniversitesi İktisadi ve İdari Bilimler Fakültesi Dergisi, 18(3), 695-720.

Ataç, Ö. (2018). Gençlerin Gençlik Merkezleri Faaliyetlerine İlişkin Tutumlarinin İncelenmesi. Yüksek Lisans Tezi. Düzce Üniversitesi Sağlık Bilimleri Enstitüsü.
Aycan, A. (2005). Gençlik Merkezlerinde Örgütsel Etkililik ve Hizmet Kalitesinin Değerlendirilmesi. Doktora Tezi, Marmara Üniversitesi Sağlık Bilimleri Enstitüsü

Devebakan, N. ve Aksaraylı M. (2003). Sağlık Hizmetlerinde Algılanan Hizmet Kalitesinin Ölçümünde Servqual Skorlarının Kullanımı ve Özel Altınordu Hastanesi Uygulamas1. Dokuz Eylül Üniversitesi Sosyal Bilimler Enstitüsü Dergisi, 1(5), 38-5444.

Demirel, Y., Yoldaş, M. A. ve Divanoğlu, U. S. (2009). Algllanan Hizmet Kalitesinin Tatmin, Tavsiye Davranışı ve Tercih Üzerine Etkisi: Sağllk Sektöründe Bir Araştırma. Akademik Bakış Dergisi, 16(10).

Gediz, S. (2012). Kamu Hizmeti Olarak Rekreasyon Etkinlikleri Kapsamında Gençlik Hizmetleri ve Spor il Müdürlükleri Bati Akdeniz Bölgesi Gençlik Merkezleri Analizi. Akdeniz Üniversitesi Sosyal Bilimler Entitüsü. Yüksek Lisans Tezi.

Göndelen, D. (2007). Öğretmen Evlerinde Hizmet Kalitesi, Müsteri Tatmininin Ölçülmesi Uygulaması ve Müssteri Tatminini Arttırmaya Yönelik Ĕgitim Modeli. Yüksek Lisans Tezi, Gazi Üniversitesi, Eğitim Bilimleri Enstitüsü, Ankara.

GSB. (2018). Gençlik ve Spor Bakanlığ1 Bütçesi TBMM Plan ve Bütçe Komisyonu Raporu. Erişim: 03.04.2018

http://www.gsb.gov.tr/HaberDetayla ri/3/145120/genclik-ve-sporbakanligi-butcesi-tbmm-plan-vebutce-komisyonunda-kabuledildi.aspx

Mucuk, İ. (2001). Pazarlama Ilkeleri. Türkmen Kitabevi, İstanbul. 
Özer, Y. E. (2011). Gençlerin Toplumsal Yaşama Katılımı ve Yerel Yönetimlerin Rolü. Dokuz Eylül Üniversitesi Iktisadi ve İdari Bilimler Fakültesi Dergisi, 11, 4365 .

Parasuraman, A., Zeithaml, Valarie, A. and Berry Leonard, L. (1988). Servqual: A Multiple Item Scale For Measuring Consumer Perceptions of Service Qality Journal of Retailing; Greenwich Vol. 64, Iss. 1, (Spring): 12.

Parlar, F. M. ve Çelebi, M. (2011). Avrupa Birliği Gençlik Projelerindeki Yönetsel Sorunların Belirlenmesi. Spor Ekonomisi ve Yönetimi Kongresi. 12-15 EKİM İzmir.http://www.sporbilim.com/dos yalar/sem.pdf

Polat, E., Aycan, A., Üzüm, H., \& Polat, E. (2013). Gençlik Merkezlerinde Algilanan Hizmet Kalitesi Ölçeği" Geçerlik Ve Güvenilirlik Çalişmasi. Spor Bilimleri Dergisi, 24(1), 25-36.

Rust, R.T., Zahorik, A.J. and Keiningham, T.L. (1996), Service Marketing, Harper Collins College Publishers, New York.

Usta, R. ve Memiş S. (2009). Hizmet Kalitesi ve Marka Bağlılığı Arasındaki İlişki Üzerine Müşteri Tatmininin Aracılık Etkisi. Atatürk Üniversitesi İktisadi ve İdari Bilimler Dergisi, 87-102. 